\title{
Constructing Learning-by-Doing Pedagogical Model for Delivering 21st Century Engineering Education
}

\author{
Ghassan Frache ${ }^{1}$, Hector Nistazakis ${ }^{2}$, George Tombras ${ }^{*}, 2$ \\ ${ }^{1}$ Abu Dhabi Vocational Education \& Training Institute, United Arab Emirates \\ ${ }^{2}$ Division of Electronics, Computers, Telecommunications and Control, Dept of Physics, National and Kapodistrian University of \\ Athens, 15784 Athens, Greece
}

\begin{tabular}{l} 
A R T I C L E I N F O \\
\hline Article history: \\
Received: 05 November, 2017 \\
Accepted: 09 January, 2018 \\
Online: 30 January, 2018 \\
\hline Keywords: \\
Higher education \\
Learning-by-Doing (LBD) \\
Pedagogical \\
$21^{\text {st }}$ Century skills \\
Pragmatic
\end{tabular}

\section{Introduction}

This study of students' and instructors' perception of the implementation of Learning-by-Doing and 21 st Century skills was conducted in Higher Colleges of Technology, HCT, a tertiary education institution in the United Arab Emirates (UAE). This research is an extension of work presented at the 2017 Global Engineering Education Conference [1]. Additionally, the work is part of thesis work for doctoral studies. The 2003 Emiratisation program, developed for the purpose of training Emiratis to become competitive, has been strictly enforced by His Highness Shaikh Mohammad Bin Rashid Al Maktoum, the Vice President and Prime Minister of the UAE (2012) [2]. The Emiratisation program is aligned with the UAE Vision 2021[3], which aims to develop and train Emiratis for taking up jobs in the country. Among other things, Vision 2021 foresees higher education as an environment where students will "enrich their minds with the skills that their nation needs to fuel its knowledge economy" [3, p. 16]. Thus, it

\footnotetext{
*Corresponding Author : G.S.Tombras, National and Kapodistrian University of
} Athens, 15784 Athens, Greece, gtombras@phys.uoa.gr can also be observed that part of Vision 2021's directive is for the UAE universities to "listen closely to the needs of Emiratis and of their future employers" and to "balance their teaching to the demands of the workplace" [3, p. 16]. Teaching methods and approaches need to be aligned with this requirement of matching the students' learning with practical needs of jobs in future, and Learning-By-Doing is one method that is gaining a reputation for doing just that [4]. This study is therefore conducted in a tertiary educational institution in the United Arab Emirates (UAE), with the aim of evaluating the pedagogical approach in the context of the framework of 'Learning-By-Doing'.

The concept of a more authentic, relevant learning has been a focus for educators since the time of John Dewey in the early part of the last century. Dewey's concept of "learning by doing" was based on his understanding that people learn best when they are actively involved in tasks that have meaning and importance [4]. In this last century, education has also been shaped by our growing understanding of how people learn. Johnson, Johnson and Holubec [5] argued that the work of Vygotsky in the 1920s, Jean 


\section{G. Frache et al. / Advances in Science, Technology and Engineering Systems Journal Vol. 3, No. 1, $115-124$ (2018)}

Piaget's cognitive development stages, Bloom and his now famous taxonomy, Howard Gardner's multiple intelligences and other related research studies have deepened our understanding of human learning, which, as [4] advocated should involve all aspects concerning the mind, hands and heart. Additionally, the principle of Learning-By-Doing is manifested in many of today's learning theories. Experiential learning, under which falls-active learning (whose subsets include cooperative learning and collaborative learning) and service learning - all exemplify the principle of Learning-By-Doing [6]. According to Voogt and Roblin [7, p. 29], in order for students to be successful in the 21 st century, not only are certain skills necessary but these specific skills also need to be taught through (and are best supported by) "specific pedagogic techniques, such as problem-based learning, cooperative learning, experiential learning, and formative assessment", which again is encompassed in the approach of Learning-By-Doing [6].

The study aims to answer the overarching research question: What constructively aligned Learning-by-Doing pedagogical model, with the incorporation of 21 st Century skills, needs to be developed to effectively teach and prepare engineering students at the Higher College of Technology, UAE for successful long-term employment in the global working economy? The main objectives of the research are as follows:

- To analyze the current understanding of LBD from the viewpoint of the engineering college's dean and instructors.

- To identify what LBD practices are being successfully implemented in the engineering department, from the perspectives of instructors and students in HCT.

- To identify what 21 st Century skills are intentionally or incidentally taught and assessed in the practice of LBD, from the perspectives of instructors and students in HCT.

- To identify what pedagogical model might best meet the needs of implementing LBD and 21st Century skills in the engineering faculty at HCT.

The following sub-questions were formulated to guide the two phases of the study and provide conclusions:

RQ1. What are the current understandings of LBD from the viewpoint of the engineering dean and the instructors?

RQ2. From the perspectives of engineering instructors and students, what LBD practices are successfully implemented in the engineering department?

RQ3. From the perspectives of instructors and students, what $21 \mathrm{st}$ Century skills are taught and assessed in the practice of LBD?

RQ4. What pedagogical model might best meet the needs of implementing LBD and 21st Century skills in the engineering division at HCT?

\section{Research Locale and Participants}

The UAE is identified by PISA (Programme for International Student Assessment) as one of the most rapidly improving education systems in the world [9]. The UAE government recognizes that in 21 st century economies, knowledge and skills have become so essential that a high value is placed on building a world-class education system that nurtures the minds and hearts of the UAE citizens. The government of UAE plays a dominant role in education, for schools and universities. It typically controls curricula even at private schools [9]. Most instructors are government employees, and most education is publicly financed up to the degree level. There are several types of post-secondary institutions in the UAE. A university offers degrees in several disciplines and usually offers graduate studies, while university colleges focus on one major discipline and are mostly for bachelor degrees. Technical institutes offer two- or three-year diplomas and are common throughout most of the region, accounting for onethird of all post-secondary students.

The UAE has more than 30 foreign academic institutions. The establishment of those institutes is a manifestation of the globalization of higher education and an indication of some of the UAE's attempts to become a knowledge-based society. Public universities in the UAE have separate colleges for males and females, following Islamic traditions. Such is the case with HCT, the locale of the present study.

HCT is one of the public's higher education institutions in the UAE, established in 2006. All the engineering programs are internationally recognized by accrediting bodies specifically the American Accreditation Board for Engineering and Technology (ABET). Because the proposed model is specific to the engineering department of HCT, the participants are its stakeholders: the engineering dean, the instructors teaching major courses in engineering and the engineering students. Only the instructors who have signed an informed consent to participate in the research were interviewed and observed. Table I shows the number of participants who were invited and participated in the study.

Table I: Participants of The Study

\begin{tabular}{|c|c|c|c|c|c|c|}
\hline Colleges & $\begin{array}{c}\text { Year } \\
\mathbf{1}\end{array}$ & $\begin{array}{c}\text { Year } \\
\mathbf{2}\end{array}$ & $\begin{array}{c}\text { Year } \\
\mathbf{3}\end{array}$ & $\begin{array}{c}\text { Year } \\
\mathbf{4}\end{array}$ & Instructors & Dean \\
\hline $\begin{array}{c}\text { MZC Colleges } \\
\text { (women) }\end{array}$ & 18 & 15 & 0 & 0 & 2 & \\
\hline $\begin{array}{c}\text { RUC colleges } \\
\text { (women) }\end{array}$ & 31 & 16 & & & 3 & \\
\hline $\begin{array}{c}\text { RUC colleges } \\
\text { (men) }\end{array}$ & 30 & 41 & 32 & 18 & 3 & \\
\hline Total & 79 & 72 & 32 & 18 & 8 & 1 \\
\hline
\end{tabular}

\section{Significance of the Study}

The researcher believe that while LBD may be translated into various strategies that call for student-centered activities, an explicit definition based on shared understanding, contextualized to how LBD should be applied in the HCT colleges, would make its practice more focused. This has the potential to greatly contribute to achieving the college's mission of providing educational experiences that will infuse its graduates with "the knowledge, skills, and attributes to effectively contribute to the nation-building process and to help them develop a sense of personal and social responsibility".

(http://www.hct.ac.ae/about/learning-model).

Additionally, the researcher sees the viewpoints of HCT major stakeholders as vital in developing explicit foundational commitments from the college community in lieu of one solely determined by higher management and handed down to teachers 
for mandated implementation. Hence, the researcher takes into account the teachers, the students, and the management's viewpoints. It is anticipated these findings will contribute to the development of an explicit model that will help the teachers focus methodologies, assessments, and other pedagogical activities not only to the principal elements that comprise LBD but also for the promotion of learned 21 st Century skills developed amongst students.

\section{Implications for the Present Research}

Although the literature does not provide any explicit definition of LBD, it links it to a number of important elements that ultimately promote its philosophy. This gives a more definitive idea of what it involves and a basis for investigating how the HCT instructor individually understands and practices the philosophy of LBD under the guidance of the college. The following is an analysis of what LBD involves:

- Learning to do (skills) not just to know, [10] - [11];

- Learning that is experiential [11], [12], active [10], [1],[13], [14], collaborative and cooperative [15];

- Learning that occurs in the context of a goal that is relevant and interesting to the student [2], [16];

- Learning that is planned (not discovered) [16], [2];

- Learning that involves not only quality academic reflection[17], [18] but civic (global) and personal experiences as well [18];

- Learning that considers the students' cultural context [19], [20] and respects every student's experience and builds upon these [11], [16];

- Learning that involves practical experiences in the context of relevant tasks closely related to how students will use it outside the learning environment [1], [5];
- Learning that involves strategies such as presentation, reports, team building, online contact time with students, critical thinking, studio teaching, team projects, and open-ended problem solving [20], [21] - [22];

The literature reviewed leaves no doubt as to the importance of 21 st Century skills in today's education, particularly to engineering education. The review has also shown that a number of 21 st Century skills take their roots from Dewey's (1899) work, among others.

Also, as mentioned in the research reviewed, over and beyond foundation knowledge taught through content engineering courses, the following are deemed indispensable 21 st Century skills applied to an engineering education. The researcher adopts Mishra and Kereluik's re-categorization of 21 st Century skills in presenting these.

\section{Meta knowledge}

- critical and self-critical abilities/problem solving, [23] - [25];

- communication and collaboration, [23] - [26];

- teamwork [23] - [27];

- creativity/innovation [23];

2. Humanistic knowledge

- life and job skills [23], [25], [26]

- ethics and cultural knowledge [26];

Interestingly, the LBD elements as listed above align with a number of the 21 st Century skills reflected in the HCT learning model. To fully explore the alignment between LBD elements and 21 st Century skills necessary in engineering education as outlined in the learning outcomes of HCT, a brief analysis by the researcher is presented in Table 2 .

Table 2: Alignment Between LBD Elements, $21^{\text {st }}$ and HCT Learning Model

\begin{tabular}{|c|c|c|}
\hline LBD elements & 21st Century skills & HCT learning outcomes \\
\hline $\begin{array}{l}\text { Learning to do (skills) not just to know (factual } \\
\text { knowledge); experiential, active, cooperative, } \\
\text { collaborative learning }\end{array}$ & $\begin{array}{l}\text { creativity/innovation } \\
\text { life and job skills/communication and } \\
\text { collaboration } \\
\text { teamwork }\end{array}$ & $\begin{array}{l}\text { Critical and creative thinking } \\
\text { Vocational competencies } \\
\text { Communication literacy } \\
\text { Teamwork and leadership } \\
\end{array}$ \\
\hline $\begin{array}{l}\text { Learning that occurs in the context of a goal } \\
\text { that is relevant, meaningful and interesting to } \\
\text { the student }\end{array}$ & $\begin{array}{l}\text { life and job skills } \\
\text { communication } \\
\text { critical and self-critical abilities/problem- } \\
\text { solving }\end{array}$ & $\begin{array}{l}\text { Vocational competencies } \\
\text { Communication literacy } \\
\text { Critical and creative thinking } \\
\text { Self-management and independent Learning }\end{array}$ \\
\hline - $\quad$ Learning that is planned & $\begin{array}{l}\text { all skills should be planned learning } \\
\text { outcomes }\end{array}$ & HCT learning model mandate \\
\hline - Learning that involves quality reflection & $\begin{array}{l}\text { critical and self-critical abilities } \\
\text { ethics and cultural knowledge }\end{array}$ & $\begin{array}{l}\text { Self-management and independent learning } \\
\text { Global awareness and citizenship }\end{array}$ \\
\hline - $\quad$ Learning that considers culture & ethics and cultural knowledge & Global awareness and citizenship \\
\hline $\begin{array}{l}\text { Learning that involves practical experiences in } \\
\text { the context of relevant tasks closely related to } \\
\text { how students will use it outside the learning } \\
\text { environment }\end{array}$ & $\begin{array}{l}\text { creativity/innovation } \\
\text { life and job skills } \\
\text { communication and collaboration } \\
\text { teamwork }\end{array}$ & $\begin{array}{l}\text { Critical and creative thinking } \\
\text { Vocational competencies } \\
\text { Communication literacy } \\
\text { Teamwork and leadership } \\
\text { Mathematical literacy }\end{array}$ \\
\hline $\begin{array}{l}\text { - Learning that involves strategies such as } \\
\text { presentation, reports, team building, critical } \\
\text { thinking, steam projects, and problem-solving }\end{array}$ & $\begin{array}{l}\text { communication and collaboration } \\
\text { teamwork } \\
\text { critical and self-critical abilities }\end{array}$ & $\begin{array}{l}\text { Critical and creative thinking } \\
\text { Teamwork and leadership } \\
\text { Communication literacy } \\
\text { Mathematical literacy }\end{array}$ \\
\hline
\end{tabular}


Biggs [28] instructional design, constructive alignment, aside from fully supporting LBD as it espouses experiential learning, sees the usefulness of an LBD structured system of learning in engineering education [29], [30]. The researcher finds this significant in contributing directions on how to go about model construction, giving particular focus to Biggs' alignment of learning outcomes, teaching and learning activities, and assessment.

In developing the model which this study proses to do, the researcher should keep in mind that although LBD is mandated as the teaching principle of Higher Colleges of Technology and is promoted in Biggs' instructional design [28], conventional methods of teaching still have a place in the classroom [23], [31] - [33]. Hence, the researcher notes that some lessons can be taught through interactive, high-level psychological lectures and activities rather than behavioral, experiential ones.

Additionally, following Houghton [34] and Fung [29] propositions, criterion-based assessments will be looked into while keeping in mind Voogt and Roblin's recommendation that while summative and formative assessments are useful in assessing 21 st Century skills, new forms of assessment should build on previous assessment practices and should be considered as a starting point.

\section{Research Methodology}

As mentioned, HCT has mandated the use of LBD and 21st Century skills learning, having adopted these at the heart of its strategic directions. At this point, it is important to delve into how LBD is implemented and how 21st Century skills are infused especially from the collective perspectives of the different stakeholders - students, instructors, and the dean.

Keeping in view the pragmatic stance that reflects the belief that human experiences are multifaceted, and that agreement concerning what is and what should be in any given situation is best negotiated among all concerned parties, the mixed method approach was selected as the best-suited method for this study. The selection of the mixed method approach was in keeping with the stance of Venkatesh, Brown, and Bala [35] who state that "such work can help develop rich insights into various phenomena of interest that cannot be fully understood using only a quantitative or qualitative method" (p. 21). Creswell and Plano Clark [36] claim that using both qualitative and quantitative methods enables the researcher to reach a more comprehensive response to the research questions, as opposed to the possible limitation of using only one method. Using the mixed methods design in this research has enabled reliable and valid data to be elicited, as it helped the researcher in obtaining data from different sources using different approaches - in-depth interviews, observations, quantitative surveys, and document analysis. Migiro and Magangi [37] state that there are three important advantages of this method:

(1) A researcher can use strengths of an additional method to overcome the weaknesses in another method by using both in a research study;
(2) Mixed method research can provide stronger evidence for a conclusion through convergence and corroboration of findings;

(3) Mixed method research can add insight and understanding that might be missed when only a single method is used (p. 3763).

Hussein [38] states that using multiple ways of data collection in the same study increases the credibility of the study (p. 1). He asserts that using mixed methods achieves more accurate and reliable findings with richer information.

The use of mixed methods is therefore grounded in the researcher's belief that findings from each set of participants (students, teachers, and the dean of engineering) will give not only a richer depiction of the findings but also a unique description of what LBD practices and 21 st Century skills are currently implemented at HCT.

\section{Quantitative Tools}

Quantitative methods are often used in social science to acquire knowledge by manipulating data through sophisticated quantitative approaches, such as multivariate statistical analysis [22]. The engineering students were requested to repond using Likert-scale questions by employing an online survey framework that was used by the researcher. Keeping in mind participant fatigue, the questionnaires were divided into two sets: LBD elements and 21 st Century skills. The sets were administered separately, a week after the other.

\section{Qualitative Tools}

The qualitative data collection was selected in order to offer the researcher an in-depth perspective regarding the personal experiences. Reference [23] provided a succinct definition that "qualitative research seeks to discover new knowledge by retaining complexities as they exist in natural settings." Reference [24] provides a description of a variety of data collection tools used in qualitative studies: interviews; data analysis; direct observations; and reporting. The choice of tool is influenced by the skill of the researcher, data collection strategy, the type of variable, the accuracy required, and the collection point [21].

\section{Data Analysis}

The following data analysis approach was shaped by the type and amount of data collected and made extensive use of description in addition to a number of statistical analyses of the quantitative data. The primary data sources, survey questionnaires, semi-structured interviews, content analysis and over classroom observations, were analysed and reported in terms of patterns in participants' responses in relation to the main and enabling research questions that guided the study.

\section{1) Quantitative Data Analysis}

To test whether the actual values are significantly different from the expected values, the chi-square test was applied to the LBD and 21 st Century questionnaire. A null hypothesis signifies that there is no statistically significant difference and an alternate hypothesis states the opposite. Based on the results of the above 


\section{G. Frache et al. / Advances in Science, Technology and Engineering Systems Journal Vol. 3, No. 1, $115-124$ (2018)}

test, the researcher can either reject or fail to reject the null hypothesis. The techniques and methods used in this study encompass the following: The descriptive analysis by using the mean and standard deviations was conducted for the items determining the 21 st Century skills.

\section{2) Qualitative Data Analyses}

To analyse the qualitative data, the audio recordings of the interviews and transcripts of the recordings were entered into nVivo software for coding and further analysis.

\section{Data Analysis and Results}

This section discusses the findings stemming from the quantitative and qualitative data collected. The quantitative methodology tools used are questionnaires given to one particular type of stakeholders, specifically the engineering students. A descriptive analysis was carried by using the frequencies and proportions. The Likert-scaled data of Learning-by-Doing items were tested for statistical significance by using a Chi-squared test. A descriptive analysis using the frequencies and proportions was conducted for the items determining the 21 st Century skills. The qualitative methodology tools used are semi-structured, one-onone interviews among the two sets of target participants: the engineering instructors and the dean.

\section{A. Descriptive statistic Learning-by-Doing survey findings}

The first questionnaire was administered to the engineering students seeking to understand how LBD is manifested inside the classroom. Students were given a set of 16 statements and then asked to rate the frequency of these statements. The statements were geared to correspond to LBD principles as opposed to LBD techniques. The survey questionnaire was administered to 184 engineering students. Students' ratings of each of the statements are listed in Table 3. Frequencies, Means, and Standard Deviation data analysis are shown. In addition, a graphical representation for the rating of LBD statement is shown in figure 1.

The first statement provides emphasis on activities done in the classroom which emphasizes collaboration as its main ingredient. Only $26 \%$ of the participants stated that this is always the case with $32 \%$ stating this is usually done. The second statement aims to find out whether there is a meaningful interaction between students and instructors during discussions. 32\% stating this is always done. The third statement emphasizes reflection on activities conducted. This is one of the hallmarks of Learning-byDoing. More than $50 \%$ of the students said it was done at least 4 times in six situations. The fourth and fifth statements are related to each other as they tackle the issue of learning "life skills," another characteristic of LBD. We can safely say more than 50\% of students are saying these are being done 4 out of 6 situations. The 6th statement's aim was to ferret out whether "Active Learning" is happening in the classroom. This statement garnered the lowest number 5 rating (12\%). The 7 th statement refers to the use of simulation in the classroom. The results on this question are encouraging considering it has a high rate of "Usually" (38\%). The demonstration of a concept is the emphasis of the 8th statement. Looking at the results, it can be seen that it has the highest points garnered in the data spectrum of "Always" (30\%). The 9th statement belongs to the purview of "Active Learning," conducting drills and practice. The results show that this statement has the highest frequency number for the rate of "Usually," garnering a whopping 44\%. The 10th statement is part of the reflection phase of LBD where students are supposed to retrospect on what they have learned. The combination of the "Usually" and "Always" frequency score however still ensures that more than $50 \%$ of the participants believe that this happens. The 11th statement touches the post-evaluative aspect. LBD encourages different ways of evaluation to encourage the participation of the learner or learners in this phase. We can still conclude that more than $50 \%$ of students believe that this happens 4 times out of 6 situations. The 12th statement is part of the real-life learning of LBD were activities that encourage more "learner" immersion is an integral part. Suggested by the statement itself are workshops and field trips. This statement got the highest "Never" and "Almost Never" frequency score. The 13th statement is still within the context of real-life learning. The 14th statement is within the purview of "Active Learning," with at least $50 \%$ of the participants believing that this occurs in 4 out of 6 situations. The 15 th statement is within the coverage of post-evaluation and reflection. Students are asked to record their impressions on a phase by phase basis. Almost $60 \%$ of the participants believe that this happens in at least 4 out of 6 situations. The 16 th statement focuses on hand-ons, kinesthetic activities. This statement got the highest "Occasionally" rate, having 40\%.

Table 3: Summary of Results for Each LBD Statement

\begin{tabular}{|c|c|c|c|c|c|c|c|c|}
\hline \multirow{2}{*}{\multicolumn{2}{|c|}{ LBD statements }} & \multicolumn{4}{|c|}{ Frequency \% } & \multirow[b]{2}{*}{$\begin{array}{c}\text { Sample } \\
\text { Size }\end{array}$} & \multirow[b]{2}{*}{ Mean } & \multirow[b]{2}{*}{ SD.P } \\
\hline & & 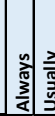 & 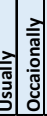 & 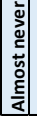 & & & & \\
\hline & $\begin{array}{l}\text { There are classroom activities that require students to } \\
\text { collaborate and learn with and from each other. Examples are } \\
\text { group proje cts that emphasize teamwork. }\end{array}$ & 2632 & 3226 & 12 & 4 & 184 & 20 & 10.2 \\
\hline 2 & $\begin{array}{l}\text { Discussions in the classroom are interactive meaning students } \\
\text { as well as the teacher contribute to the topic being discussed. }\end{array}$ & 3232 & 3225 & 9 & 3 & 184 & 20 & 12.0 \\
\hline 3 & $\begin{array}{l}\text { Questions and answers that focus on post-e valuation of } \\
\text { learning activities are conducted in the sessions. }\end{array}$ & 2533 & 3327 & 10 & 5 & 184 & 20 & 10.7 \\
\hline & $\begin{array}{l}\text { Exam questions are focused on scenarios that require students } \\
\text { to apply what they have learned and are not merely limited to } \\
\text { ones that call for memorization, definitions, etc. }\end{array}$ & 2134 & 430 & 10 & 4 & 184 & 20 & 11.4 \\
\hline 5 & $\begin{array}{l}\text { The teacher uses real life case studies as a means for teaching } \\
\text { the content of the course. }\end{array}$ & 2032 & 233 & 11 & 5 & 184 & 20 & 11.1 \\
\hline & $\begin{array}{l}\text { Students are presented with proble m-base d questions where } \\
\text { students either in group or individually will work out the } \\
\text { solutions. }\end{array}$ & 1237 & 735 & 12 & 4 & 184 & 20 & 13.4 \\
\hline & $\begin{array}{l}\text { Teacher uses simulation either digital or manual as a means of } \\
\text { teaching a concept. }\end{array}$ & 2238 & 830 & 7 & 3 & 184 & 20 & 13.3 \\
\hline 8 & $\begin{array}{l}\text { Teacher de monstrates a required subject skill first then asks } \\
\text { the students to follow suit. }\end{array}$ & 3035 & 526 & 7 & 2 & 184 & 20 & 13.1 \\
\hline 9 & $\begin{array}{l}\text { Students do drills and practice as a means of learning and } \\
\text { mastering a skill or a concept. }\end{array}$ & 2944 & $\begin{array}{ll}419 \\
\end{array}$ & 7 & 2 & 184 & 20 & 15.1 \\
\hline 10 & $\begin{array}{l}\text { Students are encouraged to reflect on what they have learned } \\
\text { and express this reflection either orally or in written format. }\end{array}$ & 2134 & 433 & 9 & 3 & 184 & 20 & 12.5 \\
\hline 11 & $\begin{array}{l}\text { In assessing student's work, the teacher uses other means in } \\
\text { addition to his/her own assessment. This other means can be } \\
\text { self-assessment or peer review. }\end{array}$ & 1536 & 630 & 11 & 7 & 184 & 20 & 11.2 \\
\hline 12 & $\begin{array}{l}\text { Teachers conduct activities that allow students to fully } \\
\text { experience the topic. Examples of these type of activities are } \\
\text { field trips and workshops. }\end{array}$ & 1629 & 933 & 14 & 8 & 184 & 20 & 9.4 \\
\hline 13 & $\begin{array}{l}\text { The college provides programs that bring students to the } \\
\text { workplace as part of the student's preparation for professional } \\
\text { working life after graduation. }\end{array}$ & 1534 & 432 & 11 & 8 & 184 & 20 & 10.8 \\
\hline 14 & $\begin{array}{l}\text { Classroom activities that ask the students to model } \\
\text { expe riences or concepts are conducted. Examples of these } \\
\text { types of activities are role-playing, reenactment or } \\
\text { walkthrough (From process to output) }\end{array}$ & 1733 & 335 & 9 & 5 & 184 & 20 & 12.2 \\
\hline 15 & $\begin{array}{l}\text { Teachers encourage students to record their impressions on } \\
\text { how they made the project on a phase-by-phase basis. This } \\
\text { requirement is in addition to the required output of the project. }\end{array}$ & 2931 & 126 & 11 & 3 & 184 & 20 & 11.1 \\
\hline 16 & $\begin{array}{l}\text { Classroom activities are formulated in such a way that students } \\
\text { can be more active and motivated in their work. Examples of } \\
\text { this type of activity are educational games and other hands-on } \\
\text { means. }\end{array}$ & 2328 & 836 & 9 & 4 & 184 & 20 & 11.9 \\
\hline
\end{tabular}


G. Frache et al. / Advances in Science, Technology and Engineering Systems Journal Vol. 3, No. 1, 115-124 (2018)

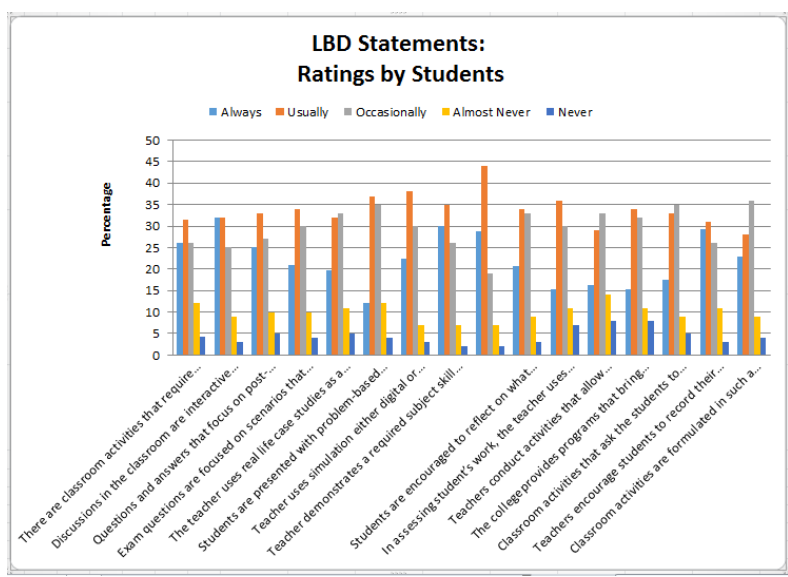

Figure 1. LBD Statements

B. Chi-Square Test on Learning-by-Doing statements

In order to determine whether there is a significant difference between the opinions of the participants regarding the LBD statements, a chi-square test for equal proportions was applied. The null and alternate hypotheses are as follows:

Null hypothesis: There is no significant difference between the opinions of the participants regarding each statement.

Alternate hypothesis: There is a significant difference between the opinions of the participants regarding each statement.

Since the p-value is less than 0.05 , we can conclude that there is little significant difference between the participants' opinions.

\section{21 stCentury skills survey findings}

To answer the 3rd question of the study, the student's point of view with regard to whether 21 st Century skills are either intentionally or inadvertently taught or assessed in the classroom was addressed. The manifestation of the skills was established in the questionnaire to crystalize the concept in the mind of the students. Students rated each category based on a 1 to 5 frequency scale. Findings of the survey results are shown in Table 4.

Table 4: Summary of Findings for $21^{\text {st }}$ Century Skills.

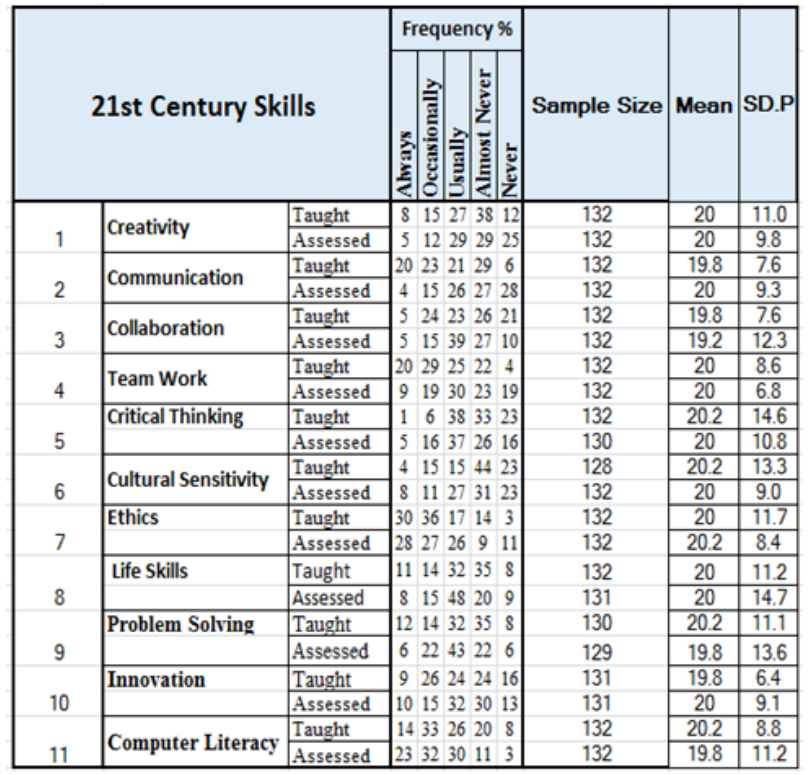

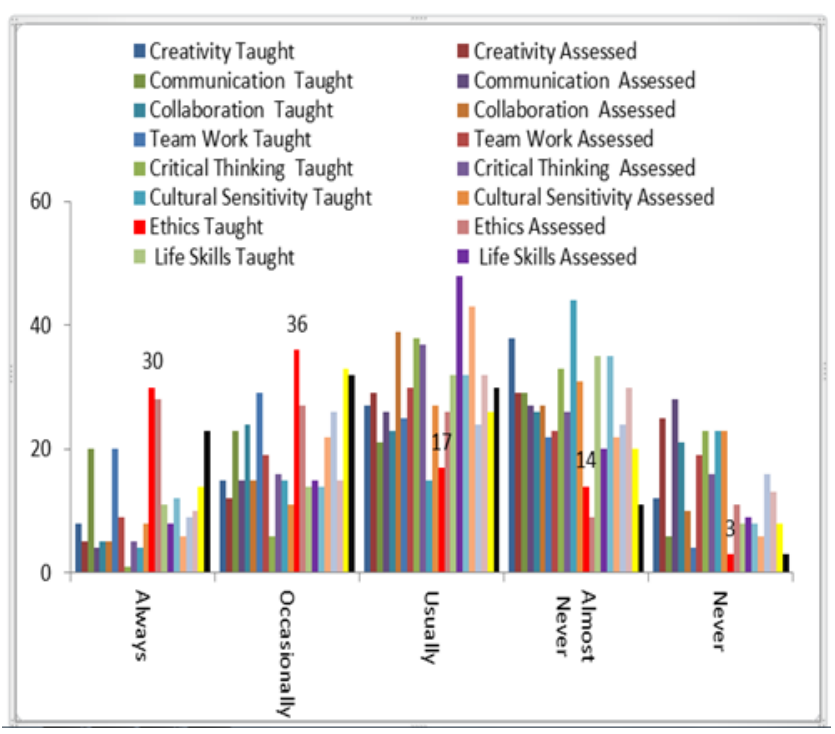

Creativity: It is observed that $50 \%$ of the students think creativity as a skill is being taught and assessed only once in 6 situations. It is interesting to note that about $54 \%$ of the participants graded 1 (never) or 2 (almost never) for they now think outside the box by exploring alternative ideas and solutions. It is interesting to note that creativity taught and assessed received $8 \%$ and 5\% respectively. This shows very little emphasis is devoted to creativity in the classroom by the teachers.

Communication: Communication skills reached the $43 \%$ in terms of students believing that it happens 4 out of 6 times in the category of taught and assessed. It would seem that communication is another skill that is not well assessed with 55\% of the students thinking that never/almost never done is happening here.

Collaboration: Looking at the taught and assessed categories, we can see that only $5 \%$ of the participants think this is done 6 times out of 6 situations and $44 \%$ think this is done 4 out of 6 situations. We can conclude that collaboration is not taught nor assessed in the classroom

Team work: Can also be considered as one of the top skills in terms of scoring as it has a more than $40 \%$ rating in the "Usually" and "Always" categories. Just like in the other skills it means 50\% of the students believe it is happening 4 out of 6 times.

Critical thinking: This skill scored lowe in both categories. These results support the obtained data from the instructor interviews about the teaching and assessment of the critical thinking skill. It is observed that $56 \%$ of the students think critical thinking as a skill is being taught and assessed only 1 time in 6 situations.

Cultural sensitivity: This skill received the highest score of $44 \%$ for "Almost Never." This highlights that almost half of the participants think that cultural sensitivity is rarely being taught in class.

Ethics: Ethics is one of the top skills that the student consistently rated high. It has 30\%, "Always" score based on the taught category, achieving the highest score among all the skills. 
Life Skills: Life skills received an average score in both categories. In the taught category Life Skills received $14 \%$ in "Usually" and $11 \%$ in "Always."

Problem Solving: The problem-solving scores $12 \%$ in the taught and $14 \%$ that this happens 4 times out of 6 situations. This is surprising result given that most of the exercises in the engineering department require laboratory and math problems. It is observed that about $35 \%$ of the participants rated "Occasionally" for classroom activities that require students to examine different processes or paradigms and apply these to different types of problems.

Innovation: Similar to critical thinking and creativity, innovation received a low percentage in "Always." It has 9\% in the taught category and $10 \%$ percent in assessed category.

Computer Literacy: In the category of "taught" alone, the combination of "Usually" and "Always" is $47 \%$ which means almost $50 \%$ of the participants agree that it happens at least 4 out of 6 times.

\section{Learning-by-Doing as explained by participants}

The study presents a discussion on the analysis of the results obtained from the primary research. The study aimed at evaluating the understanding of LBD at Higher Colleges of Technology (HCT). UAE has taken evident measures to enhance the quality of education, in order to prove its educational capabilities on the global platform. Hence, in order to assess if the government is successful in its endeavor, it was important to assess how HCT approaches and implements LBD and 21st Century skills. The research therefore aimed at understanding, from the perspectives of the teachers, students, and the dean of the Higher Colleges of Technology what constitutes of LBD and 21st Century skills, and which activities were in the process of implementation under LBD and 21 st Century skills. This is part of primary research that was undertaken by conducting using semi-structured interviews (of teachers and the dean) and surveys (of students). In addition, eight classroom observations were also used to assess first-hand the activities employed in classroom and the approach of teachers while teaching. The classroom observations were then analyzed in conjunction with the interview and the survey findings. In addition, an exhaustive analysis of the HCT curriculum was also undertaken in order to review the LBD and 21st Century related content and activities present in it.

The participants' answers can be grouped into four different classifications; mainly, the practical aspect, real world impact, and definition of LBD. From the data gathered, it can be inferred that the participants have diverse views on Learning-By-Doing practices, and it is stated to have a different meaning depending upon the type of course(s) the faculty is teaching and prior professional experience of the participant educator. Table 5 reflects the answers of the participants when asked about their understanding of LBD.

In the concept of engineering, it was claimed by one of the participants that LBD is more about working on "analytical thinking, thinking and formulating a problem, and understanding the practical application of concepts." Another participant stated that, he looks at Learning-by-Doing as a "fairly permissive term and that it is primarily focused on experiential learning." The www.astesj.com same view was shared by the engineering dean where he stated "my understanding on learning-by-doing is it's a fairly lenient term. So the first thing I would say is it hasn't got an exact definition."

Table 5. Summary of findings of LBD understanding

\begin{tabular}{|l|c|}
\hline \multicolumn{1}{|c|}{ Findings } & Occurrence \\
\hline Different meanings in different context & 1 \\
\hline Includes critical thinking & 1 \\
\hline Laboratory work & 1 \\
\hline Relevant learning experience & 1 \\
\hline Embrace all other types of pedagogy & 1 \\
\hline Hands on applicability & 1 \\
\hline Old concept & 4 \\
\hline Practical aspect of learning & 3 \\
\hline Integral part of engineering & 2 \\
\hline Supports theory & 4 \\
\hline Relating to real world & 1 \\
\hline Increase productivity of students & 1 \\
\hline $\begin{array}{l}\text { Involves careful design of activities that allows good } \\
\text { foundation for knowledge. }\end{array}$ & 1 \\
\hline $\begin{array}{l}\text { Provides an opportunity to explore and develop new } \\
\text { ideas. }\end{array}$ & 1 \\
\hline Problem solving & 4 \\
\hline Practical aspect & 4 \\
\hline Real world & 5 \\
\hline Impact of LBD & 2 \\
\hline Definition of LBD & \\
\hline
\end{tabular}

Almost all educator participants suggested during the interviews the need for a clearer and concise definition of LBD to be produced by the institution. Specifically, as one participant stated - "we need a more expansive definition of Learning-ByDoing that captures what distinguishes as well as what unites all members of engineering divisions in a shared educational enterprise." Table 6 captures the common understandings of LBD highlighted during the interviews.

\begin{tabular}{|c|c|c|}
\multicolumn{2}{c}{ Table 6. LBD defined } \\
\hline Findings & Frequency & Percentage \\
\hline Experiential learning & 2 & $25 \%$ \\
\hline Life-long learning & 1 & $12 \%$ \\
\hline Problem solving & 1 & $12 \%$ \\
\hline $\begin{array}{c}\text { Applying theoretical } \\
\text { knowledge }\end{array}$ & 3 & $37.5 \%$ \\
\hline $\begin{array}{c}\text { Apply learning to real } \\
\text { life }\end{array}$ & 3 & $37.5 \%$ \\
\hline Project-based & 1 & $12 \%$ \\
\hline
\end{tabular}

Almost all participants highlighted the importance of the union of theory and practice with an emphasis on the later. The view of marrying both theory and practice is not something new as it has been part of the LBD research literature tradition. For instance, Dewey [25] suggested the move from formal, abstract education to one that is more experienced-based. At the core of Dewey's LBD philosophy is action. Rather than merely thinking about abstract concepts, LBD involves a direct encounter with the phenomenon being studied. It utilizes actual experience with the phenomenon to validate a theory or concept [25]. It should be emphasized and pointed out that most of the participants believed that LBD is not a "stand-alone" philosophy or practice but instead intrinsically tied in with making the theory more relevant and understandable.

The experiential learning definition received the second highest percentage. This is well in agreement with widely 
published literature on LBD and in its roots of formulation as a concept and action. Experiential learning and its subsets, cooperative learning and collaborative learning, exemplify the philosophy of LBD [26]. However, as verified in the interview and follow up questions, most of the participants understood experiential learning as a type of "hands-on" learning that does not really emphasize the promotion of discussion, critical thinking, reflection, introspection, and retrospection. In this aspect, the experiential learning that most of the participants subscribe to has something to do with involving the student in the learning experience in order for the learner to understand the concept, thus this is more akin to active learning [13].

Participants were asked, "What LBD activities do you do or have you done to teach your students?" Diverse practices were encountered in classrooms to achieve LBD. Table 7 summarizes these findings.

Table 7: LBD Practices

\begin{tabular}{|c|c|c|}
\hline LBD Practices & Frequency & $\mathbf{\%}$ \\
\hline Laboratory activities/ experiment & 5 & 21.7 \\
\hline Case study & 1 & 4.3 \\
\hline Project-based & 3 & 13 \\
\hline Building & 1 & 4.3 \\
\hline Industry visit & 2 & 8.6 \\
\hline Design process & 1 & 4.3 \\
\hline Demonstration & 5 & 21.7 \\
\hline Peer Demonstration & 1 & 4.3 \\
\hline Exploration & 1 & 4.3 \\
\hline Modeling and non-routine problems & 1 & 4.3 \\
\hline Problem-based & 2 & 8.6 \\
\hline
\end{tabular}

The highest observed practices are laboratory activities and demonstration with $21.7 \%$ each. With respect to hands-on courses, the instructors are observed to assess the students and train them in LBD through practical experiments and labs. Certain other answers inferred that experiential learning is not only experiental or lab work. "I think having a reflective analysis and self-criticism or guided criticism of that experiential learning exercise is something that is often missed," the dean of engineering noted. It was also inferred that one of the biggest challenges is the understanding that pedagogy is the philosophy.

\section{E. Participants view on $21^{\text {st }}$ Centure practices}

Participants were asked to answer several questions on how $21^{\text {st }}$ Century skills were adopted in their classroom activities. The engineering dean said, "UAE engineering students need to possess them in order to survive in the current corporate world." He used the term "professional skills" for $21^{\text {st }}$ century education to highlight those listed skills. Ongoing research findings reveal that to answer today's challenges, students must have the capacity to apply knowledge in practice by learning to adapt to new situations; critical and self-critical abilities; the ability to use teamwork and communication skills, with these being listed as the top three competencies needed by $21^{\text {st }}$ century engineers [27]. The dean went on to highlight the opportunities and challenges of engineering education in the $21^{\text {st }}$ century, contending that the new professional engineer not only needs to be knowledgeable in his own discipline but also needs a new set of professional skills. Table 8 summaries the $21^{\text {st }}$ Century skills findings.

Table 8: $21^{\text {st }}$ Century Skills Findings

\begin{tabular}{|c|c|c|c|}
\hline Participant & $\begin{array}{l}21^{\text {st }} \text { Century skills } \\
\text { understanding }\end{array}$ & $\begin{array}{l}21^{\text {st }} \text { Century } \\
\text { skills used }\end{array}$ & Assessed \\
\hline Dean & $\begin{array}{l}\text { The participant has a } \\
\text { clear understanding of } \\
21^{\text {st }} \text { Century skills. He } \\
\text { even defined some of the } \\
\text { skills to include } \\
\text { theirelements in the } \\
\text { assessment of students. }\end{array}$ & $\begin{array}{l}50 \% \text { of } \\
\text { courses use } \\
\text { the } 21^{\text {st }} \\
\text { Century } \\
\text { skills. }\end{array}$ & $\begin{array}{l}\text { Not really, but } \\
\text { should be } \\
\text { included with } \\
\text { clear rubric } \\
\text { during lesson } \\
\text { and assessment. }\end{array}$ \\
\hline Teacher 1 & $\begin{array}{l}\text { It seems that the } \\
\text { interviewee is unsure of } \\
\text { the definition of those } \\
\text { skills. } \\
\text { He struggles to } \\
\text { distinguish between terms } \\
\text { such as creativity and } \\
\text { innovation. }\end{array}$ & $\begin{array}{l}\text { Innovation, } \\
\text { creativity, } \\
\text { team work, } \\
\text { problem- } \\
\text { solving, } \\
\text { communicati } \\
\text { on, ethics. }\end{array}$ & $\begin{array}{l}\text { It does not seem } \\
\text { that the teacher } \\
\text { is aware of how } \\
\text { to assess his } \\
\text { students on any } \\
21^{\text {st }} \text { Century } \\
\text { skills. None of } \\
\text { these skills are } \\
\text { clearly assessed. }\end{array}$ \\
\hline Teacher 2 & $\begin{array}{l}\text { It seems the participant is } \\
\text { unclear on the definition } \\
\text { of } 21^{\text {st }} \text { Century skills. }\end{array}$ & $\begin{array}{l}\text { Team Work, } \\
\text { collaboration } \\
\text {, and cultural } \\
\text { sensitivity. }\end{array}$ & $\begin{array}{l}\text { Yes, informally. } \\
\text { Not with a set } \\
\text { of clear rubric. }\end{array}$ \\
\hline Teacher 3 & $\begin{array}{l}\text { The participant was } \\
\text { aware of the } 21^{\text {st }} \text { Century } \\
\text { skills and answered some } \\
\text { questions about their } \\
\text { definitions }\end{array}$ & $\begin{array}{l}\text { Creativity, } \\
\text { collaboration } \\
\text {, teamwork, } \\
\text { critical } \\
\text { thinking, } \\
\text { problem- } \\
\text { solving and } \\
\text { innovation. }\end{array}$ & $\begin{array}{l}\text { Yes. In a rubric. } \\
\text { Official rubric } \\
\text { tool was } \\
\text { supposed to be } \\
\text { presented to the } \\
\text { interviewees. }\end{array}$ \\
\hline Teacher 4 & $\begin{array}{l}\text { "I don't understand what } \\
\text { you mean by } \\
\text { communication." She } \\
\text { seems to understand all } \\
\text { the other skills. }\end{array}$ & $\begin{array}{l}\text { Problem- } \\
\text { solving, } \\
\text { critical } \\
\text { thinking, } \\
\text { teamwork, } \\
\text { collaboration } \\
\text {, and life- } \\
\text { skills. }\end{array}$ & $\begin{array}{l}\text { Not all are } \\
\text { assessed. } \\
\text { Problem- } \\
\text { solving, critical } \\
\text { thinking, } \\
\text { teamwork, and } \\
\text { collaboration } \\
\text { are hard to } \\
\text { assess. But } \\
\text { others I do } \\
\text { assess in LBD } \\
\text { activities. }\end{array}$ \\
\hline Teacher 5 & $\begin{array}{l}\text { Don't understand the } \\
\text { cultural sensitivity. Some } \\
\text { confusion about the } \\
\text { definitions of some skills. }\end{array}$ & $\begin{array}{l}\text { All skills are } \\
\text { used in LBD } \\
\text { activities. }\end{array}$ & $\begin{array}{l}\text { All skills are } \\
\text { assessed except } \\
\text { ethics and } \\
\text { critical thinking. } \\
\text { No rubric is } \\
\text { available. }\end{array}$ \\
\hline Teacher 6 & $\begin{array}{l}\text { The participant is clear } \\
\text { about the definition of the } \\
21^{\text {st }} \text { Century skills. }\end{array}$ & $\begin{array}{l}\text { Creativity, } \\
\text { communicati } \\
\text { on, } \\
\text { collaboration } \\
\text {, teamwork. }\end{array}$ & $\begin{array}{l}\text { All are assessed. } \\
\text { Some might } \\
\text { have an indirect } \\
\text { assessment. No } \\
\text { rubric } \\
\text { presented. }\end{array}$ \\
\hline Teacher 7 & $\begin{array}{l}\text { The participant seems to } \\
\text { understand } 21^{\text {st }} \text { Century } \\
\text { skills. }\end{array}$ & $\begin{array}{l}\text { Teamwork, } \\
\text { collaboration } \\
\text { almost all of } \\
\text { the } 21^{\text {st }} \\
\text { Century } \\
\text { skills. }\end{array}$ & $\begin{array}{l}\text { All indirectly } \\
\text { assessed. No } \\
\text { rubric is } \\
\text { available. }\end{array}$ \\
\hline Teacher 8 & $\begin{array}{l}\text { The participant was not } \\
\text { aware of the distinction } \\
\text { between innovation and } \\
\text { creativity. Also, he did } \\
\text { not understand the use of } \\
\text { life skills in classrooms. }\end{array}$ & $\begin{array}{l}\text { Collaboratio } \\
\text { n, team } \\
\text { work, ICT } \\
\text { and life } \\
\text { cultural } \\
\text { sensitivity is } \\
\text { used. }\end{array}$ & $\begin{array}{l}\text { None of the } \\
\text { skills are } \\
\text { assessed } \\
\text { directly. }\end{array}$ \\
\hline
\end{tabular}


It is obvious that not all participants understood what $21^{\text {st }}$ Century skills are, let alone what the definition is or what the included activites are. This is despite the fact that a working definition of the skills was sent to them before they started teaching their courses at the beginning of the semester. While the participants understood the general meaning of the terms, they are at a loss when they are asked about them in the context of their inclusion in classroom activities and assessments. This is not surprising since most of the assessments of engineering subjects are technical in nature which means they usually use a quantitative approach. Skills such as collaboration, creativity, innovation, ethics, and cultural sensitivity would seem to require a qualitative evaluation framework in order to be assessed. $90 \%$ of the participants admitted that they do not include a majority of these skills as part of their assessment. When pressed with a follow-up question on the reason why, most of them simply said it was not required in the course outline. Some ventured to say it is difficult to assess these skills as they seem to be fraught with subjectivity which to them is a departure to the objective and clear type of assessment engineering students are used to having. However, not all $21^{\text {st }}$ Century skills were unfamiliar to the participants. A clear majority of them stated that technological literacy, problemsolving, teamwork, ethics, and collaboration are mostly included in their assessment tools.

F. View of the participants towards incorporating the LearningBy-Doing and $21^{\text {st }}$ Century skills better in the course outline

The participants also provided their views on how LBD and $21^{\text {st }}$ Century skills were incorporated in the course outline. Mostly, it was stated that the course outline should include clear assessment guidelines for LBD activities and $21^{\text {st }}$ Century skills. Two of the participants emphasized the core concepts and skills students needed to learn and cautioned to avoid unconnected topics which inhibit the development of critical thinking and other $21^{\text {st }}$ Century skills. In addition, the participants also claimed that critical and creative thinking can be incorporated into the course outline, and on giving more importance to improving the communication abilities and promoting the spirit of teamwork and leadership. One of the participants specified four main skill areas that affect creativity and innovation in the current course outline: fluency, flexibility, elaboration and originality. Hence it was proposed that making these skills a part of the assessment strategy would better incorporate LBD and $21^{\text {st }}$ Century skills in the course outline. The participants also claimed that the personal and social development of the students may be enhanced by developing their managerial and leadership skills, and by preparing them to implement complex skills such as planning, communicating, problem-solving, and decision-making.

\section{Conclusion}

This study reported on data gathered from instructors and the HCT dean's interviews and student questionnaire surveys. It has shown diverse views on the Learning-by-Doing understanding, practices, and definition. While most of the educator and student participants explained their understanding of LBD, the enumeration of the impact verifies the "incomplete" understanding of LBD. On the definition of LBD, participants viewed it as the second half of "theoretical" knowledge which is its application. This understanding is supported by LBD research literature. For instance, [7] suggested the move from formal education to one that is more experienced-based. As engineering is a skill-based field, it was no surprise for the participants to award high percentage for laboratory activities and experiments to be the most used LBD activities. The importance of $21 \mathrm{st}$ Century skills was highlighted by all participants during the educator participant interviews. But, most of them failed to use them in the context of their classroom activities. Creativity, critical thinking and innovation skills were highlighted as the most difficult to assess in engineering courses. The underlying theme of the findings from the students' point of view is that nearly $55 \%$ of the students believed the LBD is conducted and assessed in the classroom. The rest of the students, $45 \%$ seem to believe that LBD is not conducted in the classroom activities. The survey data used in this study was discussed along with other interviews and personal observation data to explore the results further in the construction of the LBD model.

\section{References}

[1] G. Frache; H. E. Nistazakis; G. S. Tombras. "Reengineering engineering education: Developing a constructively aligned learning-by-doing pedagogical model for 21st Century education", 2017 IEEE Global Engineering Education Conference (EDUCON), Athens, Greece, 2017, pp. $1119-1124$

Doi: 10.1109/EDUCON.2017.7942989.

[2] Zaman, S. (2012). 2013 dedicated to Emiratisation. Gulf News. Retrieved from http:/gulfnews.com/news/gulf/uae/society/2013-dedicated-toemiratisation-1.1111015.

[3] Vision 2021 United Arab Emirates. Available: http://www.vision2021.ae/en

[4] J. Dewey, Democracy and education: An introduction to the philosophy of education. New York: WLC Books, 2009.

[5] D. W. Johnson, R. T. Johnson, and E. Holubec, Cooperation in the classroom (8th ed.). Edina, MN: Interaction Book Company, 2008.

[6] T. T. Pham. "Issues to consider when implementing student-centered learning practices at Asian higher education institutions". Journal Of Higher Education Policy And Management, 33 (5), pp. 519-528, 2011.

[7] J. Voogt, \& N. Roblin, International Symposium on Education Reform EDL. [online]. [Viewed: 2013]: ttp://www.internationalsymposiumoneducationalreform.com

[8] Organization for Economic Cooperation and Development. (2014). Better Skills, Better Jobs, Better Lives: A Strategic Approach to Education and Skills Policies for the United Arab Emirates. Paris, France.

[9] W. Rugh, "Arab education: Tradition, growth, and reform, "The MiddleEast Journal, 396-414, 2002.

[10] L. H. Lewis, and C. J. Williams, "Experiential learning: Past and present, “ New Directions For Adult And Continuing Education, vol. 62, pp. 5-16, 1994

[11] A. Y. Kolb and D. A. Kolb, "Learning styles and learning spaces: Enhancing experiential learning in higher education, " Academy Of Management Learning \& Education, vol. 4, no. 2, pp. 193-212, 2005.

[12] A. Finkel, "Innovative Approaches to Engineering Education: The Australian Experience," 2013, www.caets.org.

[13] R. Pascual, and R. Uribe, "Experiential Learning Strategies in a Mechanical Engineering Senior Course, ", paper presented at Sixth International Workshop on Active Learning in Engineering Education. Mexico: Monterrey, 2006.

[14] M. Romi, "Learning by teaching in engineering: a step beyond learning by doing, "Technology, Education And Development, A. Lazinika and C. Calafate, Eds. Croatia: Intech, 2009, pp. 337-394.

[15] P. R. Donald and J. L. Faust, "Techniques for active learning”, 2010.

[16] L. Kane, "Educators, learners and active learning methodologies", Int. Journal Of Lifelong Education, vol. 23 no. 3, 2004.

[17] S. L. Ash and P. H. Clayton, "The articulated learning: An approach to guided reflection and assessment, "Innovative Higher Education, vol. 29 no. 2, pp. 137-154, 2004.

[18] R. C. Clark and R. E. Mayer, "Learning by viewing versus learning by doing: Evidence-based guidelines for principled learning environments, 
"Performance Improvement, vol. 47 no. 9, pp. 5-13, 2008.

[19] M. Ginsburg, Active-learning pedagogies as a reform initiative: Synthesis of case studies. Washington, DC: Academy for Educational Development, 2009.

[20] R. Pascual and R. Uribe, "Experiential Learning Strategies in a Mechanical Engineering Senior Course", paper presented at Sixth International Workshop on Active Learning in Engineering Education. Monterrey, Mexico, June 2006.

[21] C. M. Vest, "Educating engineers for 2020 and beyond, "Report of a Convocation "Educating the engineer of 2020. pp. 160-169, 2005.

[22] P. Morgado, "From Passive to Active Learners: Implementing the Pedagogy of " Learning by Doing" in a Large-sized Design Foundation Class, "Transformative Dialogues: Teaching \& Learning Journal, v.4 n.2, 2010.

[23] C. M.Vest, C. M, "Educating engineers for 2020 and beyond," Report of a Convocation "Educating the engineer of 2020. pp. 160-169, 2005.

[24] L. Morell, "Engineering Education in the 21st Century: Roles, Opportunities, and Challenges," International Journal of Technology and Engineering Education, 7(2), 1-10, 2010.

[25] National Academy of Engineering (NAE) (2010) Grand Challenges for Engineering in the Eyes of 21 st Century Students. Available from http://www.edstechnologies.com

[26] K. E.Wolfe Understanding the careers of the alumni of the MIT Mechanical Engineering department, 2004.

[27] R. Pascual and R. Uribe, "Experiential Learning Strategies in a Mechanical Engineering Senior Course", paper presented at Sixth International Workshop on Active Learning in Engineering Education. Monterrey, Mexico, June 7-9, 2006.

[28] J. B. Biggs, C. S. Tang, and J. B. Biggs Teaching for quality learning at university. Maidenhead: Mcgraw-Hill/Society For Research Into Higher Education \& Open University Press, 2007

[29] S. Nightingale and A. Carew and J. Fung, "Application of constructive alignment principles to engineering education: Have we really changed," In Proceedings of the Australasian Association of Engineering Education Conference, December, pp. 9-13, 2007

[30] N.M. Meyers and D. D. Nulty, "How to use (five) curriculum design principles to align authentic learning environments, assessment, students' approach to thinking and learning outcomes," Assessment and Evaluation in Higher Education (34), pp 565-577, 2009

[31] R. Clark and R. E. Mayer, "Learning by Viewing versus Learning by Doing: Evidence-Based Guidelines for Principled Learning Environments," Performance Improvement, 47(9), 5-13, 2008

[32] L. Kane, "Educators, learners and active Learning Methodologies," International Journal of Lifelong Education, 23(3), 275-286, 2007.

[33] D. Hung and S. Lee, "Is there an instructional framework for the $21^{\text {st }}$ century?" Creative Education, 3(4), 461-470, 2012.

[34] W. Houghton, Engineering Subject Centre Guide: Learning and Teaching Theory for Engineering Academics. Loughborough: HEA Engineering Subject Centre, 2004.

[35] V. Venkatesh and S. A. Brown, and H. Bala, "Bridging the qualitativequantitative divide: Guidelines for conducting mixed methods research in information systems," MIS Quarterly, 37(1), 21-54, 2013.

[36] J. W. Creswell, and V. L. Clark, Designing and conducting mixed methods research. Thousand Oaks, Calif.: SAGE Publications, 2011.

[37] S. O. Migiro and B. A. Magangi, "Mixed methods: A review of literature and the future of the new research paradigm." African Journal of BusinessManagement. 5(10), 3757-3764. doi: 10.5897/AJBM09.082, 2011.

[ 38] A. Hussein, "The use of triangulation in social sciences research: Can qualitative and quantitative methods be combined, "Journal of Comparative Social Work, 1, 1-12, 2009. 